\title{
Gago Coutinho and the Scientific Navigation
}

\author{
André R. R. Silva, Jorge M. M. Barata, Fernando M. S. P. Neves \\ Aerospace Sciences Department, Universidade da Beira Interior, Covilhã, Portugal \\ Email: fernandomneves@gmail.com
}

How to cite this paper: Silva, A.R.R., Barata, J.M.M. and Neves, F.M.S.P. (2016) Gago Coutinho and the Scientific Navigation. Open Journal of Applied Sciences, 6, 751-769.

http://dx.doi.org/10.4236/ojapps.2016.610067

Received: July 6, 2016

Accepted: September 24, 2016

Published: September 27, 2016

Copyright $\odot 2016$ by authors and Scientific Research Publishing Inc. This work is licensed under the Creative Commons Attribution International License (CC BY 4.0).

http://creativecommons.org/licenses/by/4.0/

\begin{abstract}
Gago Coutinho, jointly with another Portuguese aerial navigator, managed to perform the First Flight from Europe to the South Atlantic in 1922, a Journey exclusively guided by internal means of navigation. Despite Coutinho being a person with multipurpose activity on several areas of knowledge, he became known and glorified in the World in 1922, as an air navigator, a position that he achieved due to an aerial navigation device that he also had invented. Coutinho developed a new sextant model that could be used to measure the altitude of a star (when flying overseas) without the need of the sea horizon. This new device was called precision sextant and was provided with an artificial horizon line defined with the help of a water bubble. Due to his knowledge of Navigation, Astronomy, Geography and Mathematics, Coutinho received from the Portuguese King D. Carlos I, several assignments at Africa and Asia. Gago Coutinho received several important official medals and prizes, including the Ph.D. Honoris Causa from the Universities of Lisbon and Oporto and authored several scientific publications. Coutinho received the distinct position of Admiral of the Portuguese Navy in 1958 and died in the following year.
\end{abstract}

\section{Keywords}

Gago Coutinho, South Atlantic Aerial Crossing, Precision Sextant, Circumnavigation Flight Attempt

\section{Introduction}

Navigation could be defined as the ability to monitor and to control the positioning of a vehicle along a starting point to a previous destination point by following a set course. Many centuries ago the very first maritime navigators often found their way through the observation of physical landmarks, such as large rocks or trees along rivers and coastlines. When out of sight of land, navigators began to derive clues about their location by measuring water depth, monitoring wind pattern and wave shape, and observing the position of the Sun as it moved across the sky; during the night, they learned how to 
be guided by the Stars. Posteriorly, navigators developed devices in order to measure more accurately the ships position as well as ships progress along a route; they began to use a magnetic compass in order to determine their direction and managed to measure the height of the Sun or Stars on the horizon, as well as to determine and to record its position. According to all previous acquired knowledge on navigation, navigators started to record previous desired routes along paths on nautical maps called charts. During the $15^{\text {th }}$ century, Portuguese explorers were traveling south along the African Coast looking up for an East route; however, as a seafarer nears the equator heading South hemisphere, the Polaris Star disappears below the horizon. So, in southern seas, Portuguese navigators had to find out a different way of finding their latitude. Under the orders of Portuguese Prince Henry, by year 1480, the Portuguese astronomers had already found a procedure (actually known as "declination") in order to determine latitude using the position of the Sun as it moved North and South of the equator line, depending on the seasons. In simple terms, a navigator could determine his "altura" (latitude) by using a device (quadrant) to find the altitude of the Sun as it came to its greatest altitude (at a local apparent midday or noon time) and then apply a simple correction for the position of the Sun (North or South of equator line, according to season). Such as ship navigation, Mankind has been obsessed by the idea of flight navigation since the dawn of recorded history. Men have always imagined themselves cavorting among the clouds, wheeling and soaring like birds. The first controlled flight in an aircraft was made on 17 December 1903 by the Wright Brothers. On 23 October 1906 the Brazilian Santos Dumont performs a public flight in Paris in his famous 14-Bis airplane. The World's first freight-carrying flight occurs on 7 November 1910, when Philip Palmalee piloted a Wright Model B biplane, from Dayton to Columbus in Ohio, U.S.A., flying 63 miles in $1 \mathrm{~h} 20 \mathrm{~m}$. The French pilot Louis Blériot flew the first maritime extension from Calais (France) to Dover (England) on 25 July 1909, nearly 27 miles. On 23 September 1913, Roland Garros flew the 475 miles from France to Algeria across the Mediterranean in $7 \mathrm{~h} 53 \mathrm{~m}$. During the World War I (1914-1918) considerable development of aeronautics occurred, although most of the results of the planning had not time to come to daylight before the Armistice. An important example is the NC-4 flying boat, designed by Glenn Curtiss, to become an alternative to the Allied shipping that was being threatened by submarine warfare. In May 1919, the NC-4 became the first aircraft to fly across the Atlantic Ocean, from New York to Lisbon in 19 days, $(4,000 \mathrm{~km}$ in 22 hours of flight); the crew orientation was supported by external means of navigation (radio and T.S.F.). 2 weeks later, the second successful transatlantic flight was achieved by John Alcock and Arthur Brown (also using T.S.F.), a non-stop flight lasting 16 hours performing 3,040 km from Newfoundland to Ireland. Before 1922, all the existing self-navigational devices were the naval ones, regarding maritime application and they could not be applied to aviation due to difficulty of the definition of the sky-line at a normal flight altitude.

\section{Aviation Need of Aerial Navigation Devices}

Gago Coutinho (Figure 1) and Sacadura Cabral were both Portuguese navigators that 
managed to perform the First Flight from Europe to the South Atlantic in 1922. In May 1919 Sacadura Cabral had a chance to meet Albert C. Read during his stay at Lisbon and managed to obtain acquaintance for subjects related to his New York-Lisbon Aerial Journey, in special about the lack of internal means of navigation onboard the seaplane; the aerial navigation along this journey had been strongly supported by ships. From 1919 onwards, the aerial navigation methods and devices became the focus of interest for Sacadura Cabral and Gago Coutinho: a question to solve a new and interesting Aviation problem. According to all knowledge acquired by Gago Coutinho on naval navigation, he stated that the air navigation problems would be solved by adapting all naval navigation devices for aerial navigation, however, taking into account the effective capacity to address the following aerial specific conditions: 1) the wind had to be determined onboard the aircraft; 2) since as the aircraft flies at high speed, it would be necessary to determine its position much faster than that practiced onboard the ships; 3 ) naval navigators needs to use the sea horizon as a way to observe the heights of the Stars; air navigators, when flying high altitudes or above the clouds, would not had the opportunity to see the sea horizon; it would be necessary to use an artificial horizon as a way to observe the height of the Stars. Gago Coutinho worked hard on a naval sextant in order to fulfill these 3 requirements and managed to build a new device called Precision Sextant (Figure 2). Precision Sextant was provided with an artificial horizon line, defined with the help of a water bubble [1]-[12]; this device was improved later with an illumination system in order to allow its use during weak light or dark night conditions

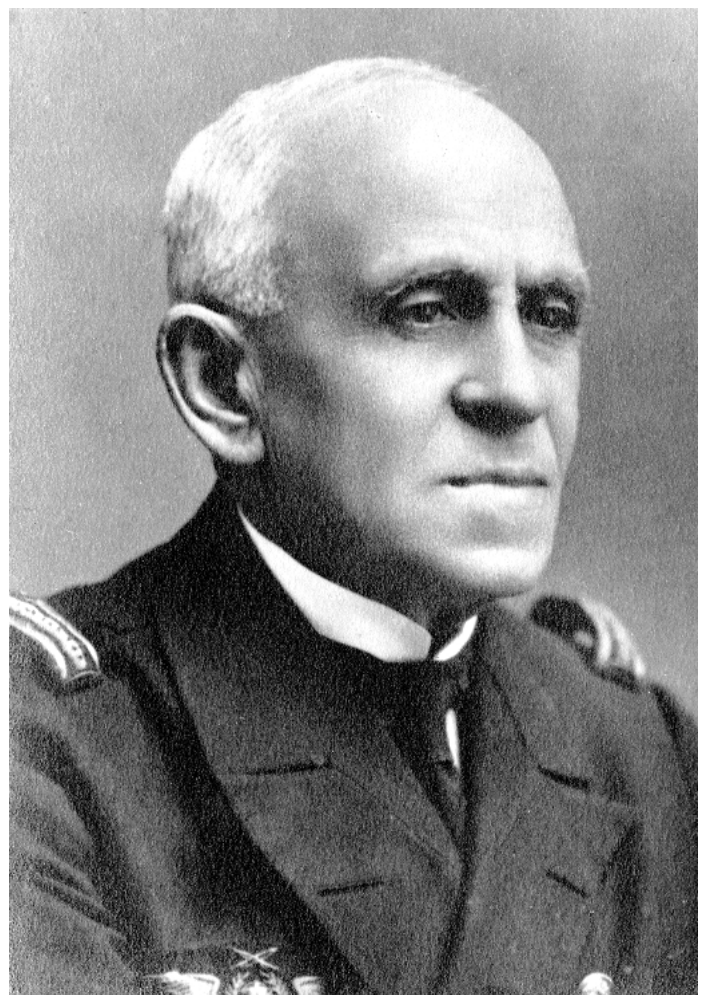

Figure 1. Portrait of Carlos Viegas Gago Coutinho [12]. 


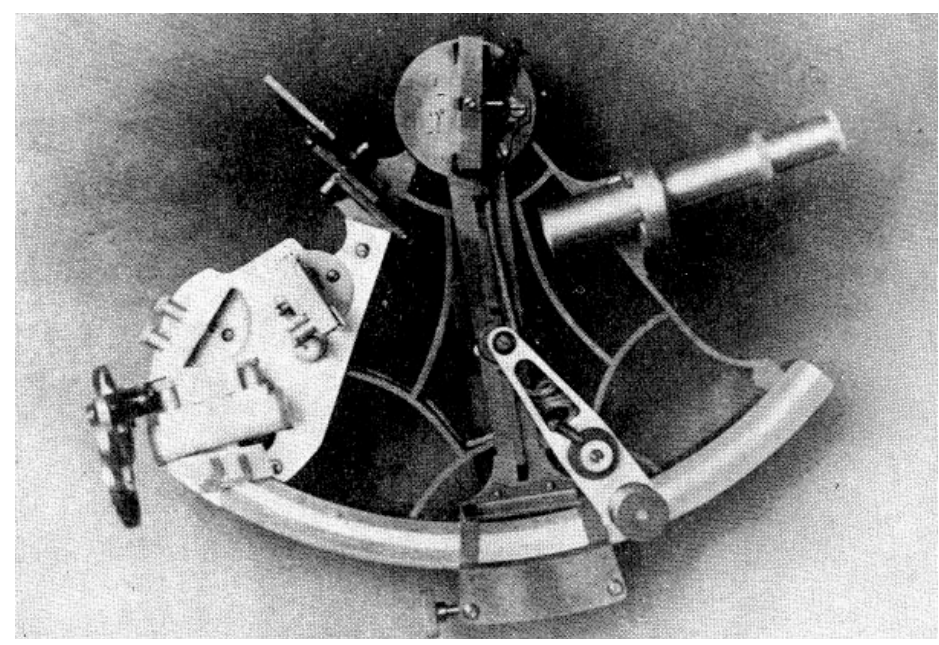

Figure 2. Precision sextant improved and used by Gago Coutinho along the First Flight from Europe to South Atlantic [3].

[3]-[6] [11]-[13]. Another instrument called "path corrector" was also developed by Coutinho and Cabral in order to calculate graphically the angle between the longitudinal axis of an airplane and the direction of flight, taking into account the intensity and the direction of the winds [3]-[6] [11]-[14]. Both navigation devices were tested during short flights from Lisbon to Madeira in 1921 and posteriorly applied with quite success on the First Flight from Europe to the South Atlantic, performed in 1922 by Gago Coutinho and Sacadura Cabral. For the first time in the Aviation History, the crossing of the South Atlantic had been achieved and using an instrument that enabled an airplane's position to be determined by astronomic navigation when flying out of sight of land.

\section{Gago Coutinho Biographical Notes}

Carlos Viegas Gago Coutinho was born at Belém, Lisbon, on 17 February 1869. In 1885 he graduates from high school and registered himself at the Polytechnic School in order to prepare its entry into the Naval Academy a year later. Its record of promotions in the Marinha de Guerra Portuguesa (Portuguese Navy) demonstrates a clear rise: on 30 October 1886-Aspiring $1^{\text {st }}$ class; on 21 January 1890-Midshipman; on 7 March 1891Second Lieutenant; on 26 October 1895-First Lieutenant; on 7 February 1907-Lieutenant Commander; on 9 December 1918-Sea and War Captain; on 30 March 1922-Rear Admiral (with distinction); on 17 August 1932-Vice Admiral and on 22 April 1958Admiral (by resolution of the National Assembly) [3]. Figure 3 illustrates Gago Coutinho portraits on different stages of his life. His work could be divided in four areas, which follows chronologically as areas for priority action: Navy, especially from 1893 to 1898; geographical works, between 1898 and 1920; air navigation, from 1919 to 1927 and history of navigation and discovery, from 1925 to 1958. Despite Gago Coutinho being a person with multipurpose activity on several areas of knowledge, he became glorified in 1922, as an air navigator. 

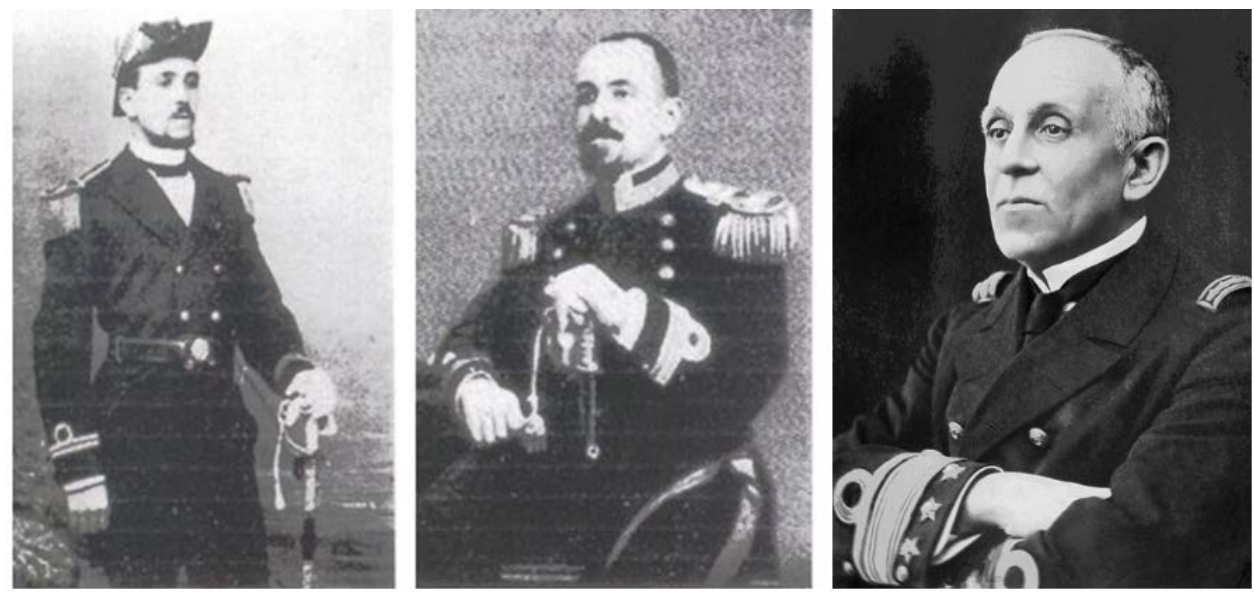

Figure 3. Portraits of Gago Coutinho at different stages of his life; left, in 1892 as $2^{\text {nd }}$ Lieutenant; middle, in 1895 as $1^{\text {st }}$ Lieutenant; right, in 1922 as Rear Admiral [3] [6].

\section{Gago Coutinho and the Aircraft Navigation}

The entire previous works performed by Coutinho along military naval duties at sea as well as all his geographical works along missions over all Portuguese Ultramarine territories at land, involved a constant use of a sextant and led Coutinho to acquire a thorough knowledge of this navigation device, both at sea and on land.

\subsection{Gago Coutinho and Naval Navigation}

In mid-December 1887 he accomplishes its first sea voyage to London as a cadet. In 7 December 1888 he embarked on the "Afonso de Albuquerque" corvette as crew member and onboard this ship he travels to Mozambique in order to join the Marine Division of East Africa, participating in the military occupation of the area of Tungue, Mozambique, to counteract the territorial ambitions of the Sultan of Zanzibar. He remains in this ship till 16 January 1891. Then follows a long list of ships which he navigated as crew member: Corvettes: "Mindelo", "Duque da Terceira”, "Rainha de Portugal" and "Vasco da Gama”; Gunboats: "Zaire", "Zambeze", "Douro", "Limpopo" and "LiberaP"; Transport ship: "Pero de Alenquer" (School-Ship): He was garrison officer on both gunboats “Limpopo" (at Angola) and "LiberaP”(at Portuguese coastline).

From his many travels, two were famous: onboard the corvette "Mindelo", under the command of Admiral Augusto de Castilho, he performs its first Luanda-Rio de Janeiro cross Atlantic voyage, exercising navigation sextant most part of the trip; and onboard the transport ship "Pero de Alenquer" (1896) he performs the cross Lisbon-Lourenço Marques, exclusively by navigation sextant, following as far as possible the historic route of Vasco da Gama on his journey to India, nearly 400 years before. This crossing as came to provide great teachings for all studies published on his book "Náutica dos Descobrimentos". On March 1898, he was invited and accepted to fulfill the first of several committees as a geographer overseas within the Portuguese Cartographic Commission, a service established in 1883. In addition to extensive and lengthy travels performed in ships moved exclusively by engine, in ships with engine and sail, or in 
ships only sailing, Gago Coutinho crossed the sea serving the Portuguese Navy, covering the South Atlantic coast to coast and the western Indian Ocean. He would get this geographer job in the following decades, although in 1911 and 1912 he conducts two more ships commands: onboard the gunboat "Sado" (on mission at Portuguese India) and onboard the gunboat "Patria" (at East Timor campaign) between April and June 1912). During a native attack, he designed a pioneering system to increase the range of the ship's artillery. It is estimated that throughout his life Gago Coutinho had performed 30,837 miles of naval navigation [3] [6]. His task assignments, onboard all the ships in which he served were almost exclusively of "officer in charge of navigation" from which resulted the knowledge of the classic sextant. Already with 75 years old, onboard the Portuguese ship "Foz do Douro" he performs a new sailing cross from Santos (Brazil) to Leixões (Portugal), 105 days using the historical astrolabe, like the ancient Portuguese sailors.

\subsection{Gago Coutinho: Geographer and Astronomer}

In 1885 the Berlin Conference on International Law devotes the recognition of effective occupation of overseas territories and calls for a more effective territorial division of the national frontiers. In 1886 Portugal signs with France and with Germany the limits of Guinea and Angola and in 1891 signs treaties with England relating to Mozambique frontier with South Africa. This work requires knowledge of Navigation, Astronomy, Geography and Mathematics. By the decision of Carlos I, King of Portugal, in 1898, Gago Coutinho receives order to develop this work. Between 27 July 1898 and 19 April 1899 he works on the East Timor demarcation frontier, where he carries out the reconnaissance of the coastline and the survey of an area of nearly 1,200 miles [3]. From 5 September 1900 to 28 January 1901 his work consisted on the delimitation of the frontier of Niassa, North Mozambique in an extension of nearly 190 miles. Later in the same year he worked in the delimitation frontier within Mozambique and British Central Africa territories. After, he went to Angola, to devote himself to the demarcation of the Noqui (North of Angola) frontier by end of 1901. Thereat he worked in the delimitation frontier of Tete, Mozambique, from 27 February 1904 to 18 December 1905. From 1907 to 1910 he worked in geodesic triangulation of Mozambique from the southern frontier to the Barotze. Barotze was part of the policy of occupation of central Africa, which is symbolized in the called "Mapa Cor de Rosa" (Rose-Colored MapFigure 4). Along 1913 and 1914 he was accompanied by several officers, among them Sacadura Cabral, and demarcated the frontier between Angola and Rhodesia. During this mission some longitudinal determinations were made by two different and innovative forms: by Moon measures, and by underwater cable. These works are considered unprecedented in the "Academia de Ciências de Portugal" (Portuguese Academy of Sciences). In 1918 he completed his work as a geographer with the triangulation of the S. Tomé and Príncipe archipelago. In this mission he determined the point over which crosses the geodetic equator-the small island "Ilha das Rolas" (Pigeon Island) that has also received his name: "Ilhéu Gago Coutinho" Islet Gago Coutinho. Within 1898-1920 


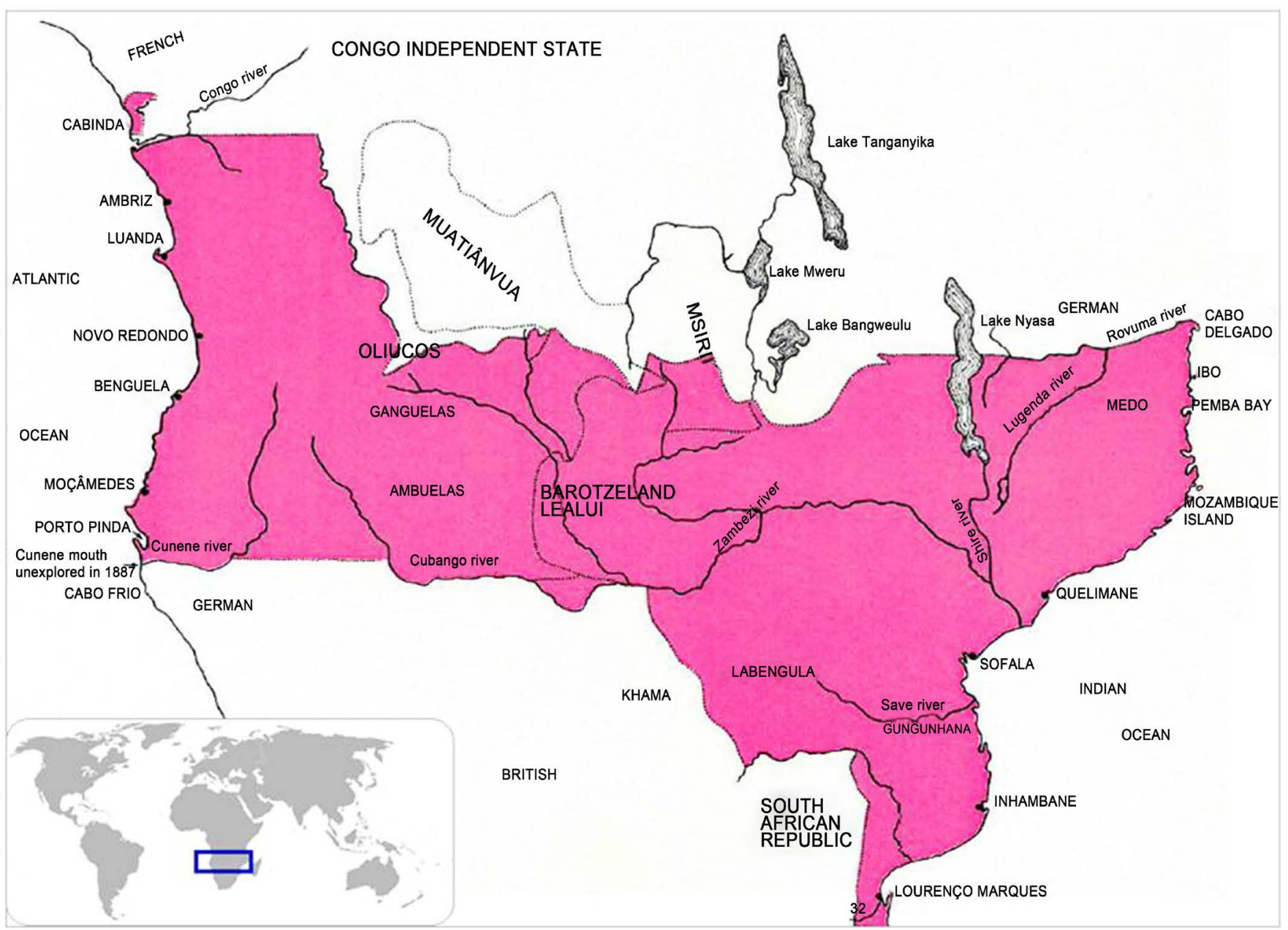

Figure 4. Detail of the final version of Rose-Colored Map published in 1887 by Portuguese Foreign Officer opposing both Portuguese and British Sovereign interests at Africa [15].

Coutinho worked on Portuguese geographical interests on almost all overseas provinces; over that time period, he delimited more than 1,250 miles of territorial frontiers and performed triangulation works in areas greater than 300 miles [3]. Along its Barotze mission he crosses Africa twice and traveled by foot nearly 3,250 miles; he walked an average of 26 miles a day during 2 consecutive months, observing in this period more than 3,000 pairs of stars; 6 of these 22 years were spent in the jungle, living outdoors and sleeping in tents. Coutinho would be also the major driver of geographical studies in Portugal. He proposed to establish the Geographer Engineer degree-this course usheredat Portugal at 1921 [3].

\subsection{Gago Coutinho: Aerial Navigator}

All Coutinho's acquired knowledge would serve as a base for further studies; his special appreciation for the unknown, adventure and machines that could change the World, were particularly inherited by the readings of Jules Verne works. His great spirit of adventure led him to travel around the world using all means of transport until he felt 
attracted by the great invention of the time, the airplane. Its first flight took place on 23 February 1917 in a Maurice Farman airplane at the Military School of Aviation in Vila Nova da Rainha (Portugal) along with the pilot Sacadura Cabral. Gago Coutinho thought that aviation was a vast area of new scientific discoveries, in which he wanted to apply all the knowledge and numerous researches that he had collected either at sea and land. The almost daily employment of the sextant carried out in Africa during his geographer missions and the detailed knowledge of the possibilities of this instrument in land and sea, were more than enough to justify his opinion. The sextant used by the navy could not be applied to aviation due to the difficulty of the definition of the sky-line at a normal flight altitude. So, he developed the precision sextant, a new model of sextant that could be used to measure the altitude of a star without the need of the sea horizon. Coutinho and Cabral developed another instrument called "path corrector" (Figure 5) to calculate graphically the angle between the longitudinal axis of an airplane and the direction of flight, taking into account the intensity and the direction of the winds [14]. These navigation instruments were tested during short flights between 21 July 1920 and 21 January 1921. The use of these devices was complemented by the use of Auss tables, or with the collection of Houel tables. In 22 March 1921 an experimental flight was made from Lisbon to Madeira (520 nautical miles-Figure 6). The Lisbon-Madeira trajectory should be a perfect straight line, and to verify the position of the aircraft three ships were used to control the seaplane position. The result was a complete success and he started to believe that they were prepared to initiate the trans-

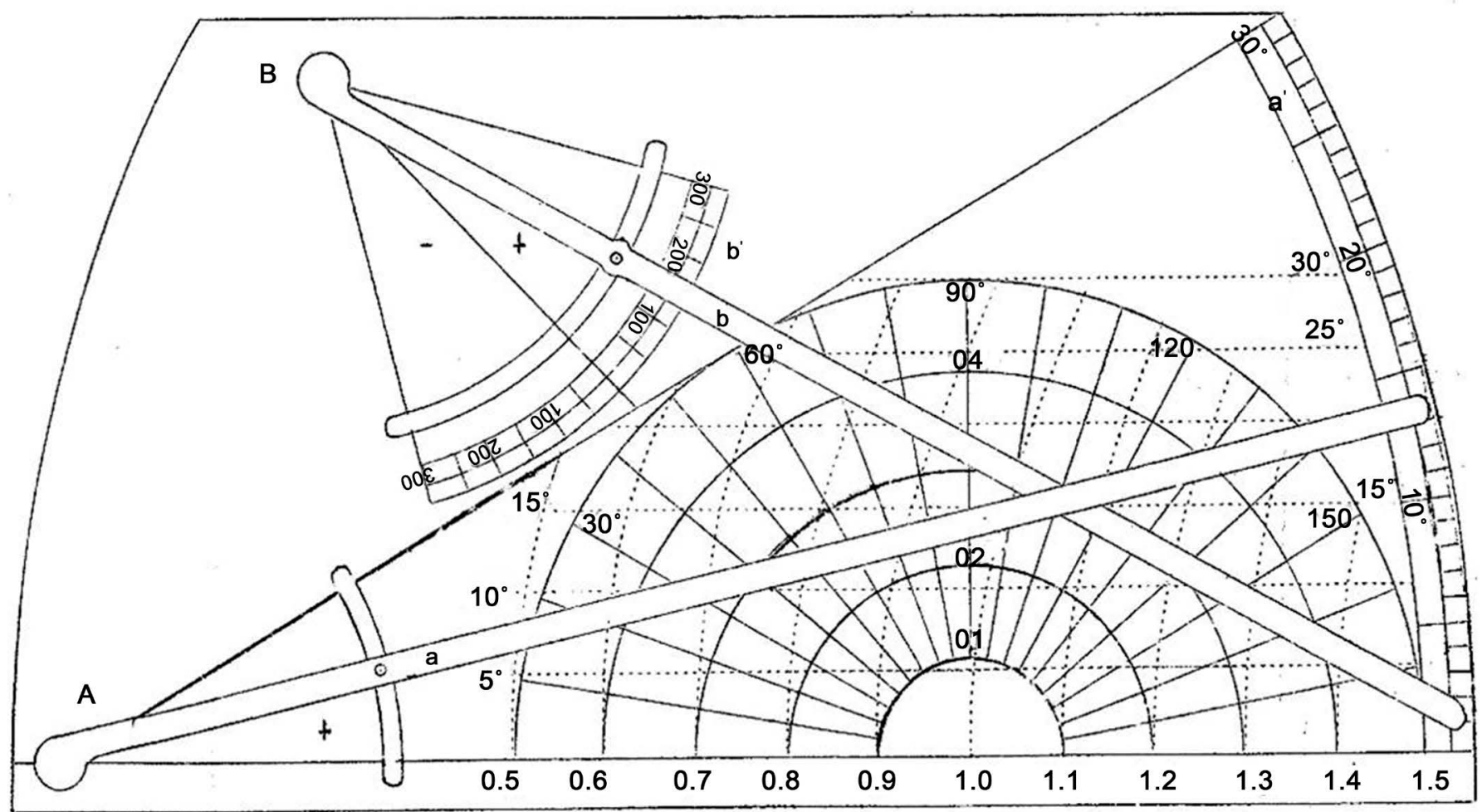

Figure 5. The path corrector invented by Gago Coutinho and Sacadura Cabral [14]. 


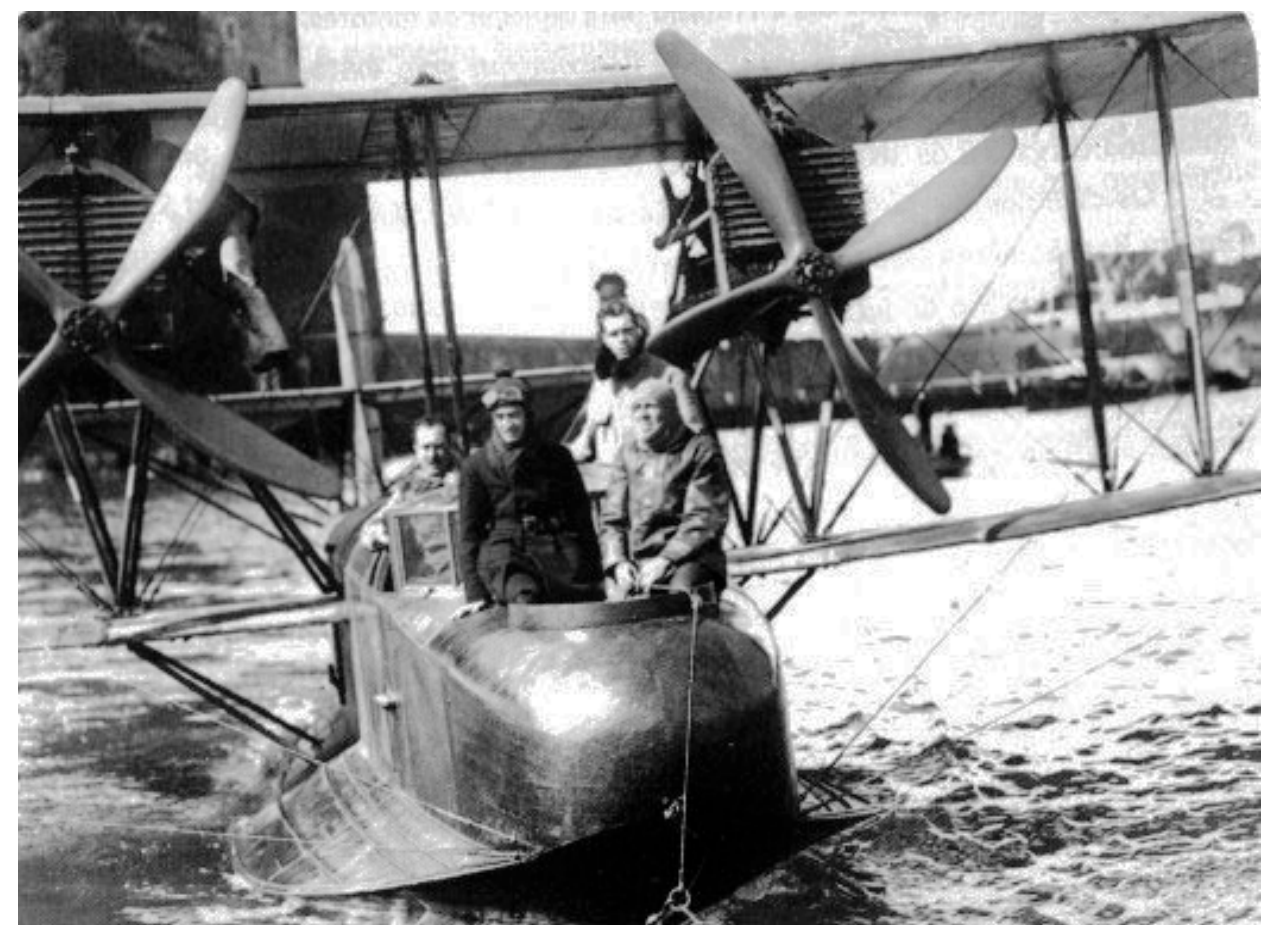

Figure 6. The navigator Gago Coutinho onboard a Felixtowe, a Portugueses Naval Aviation seaplane, arriving at Funchal (Madeira) along an experimental flight from Lisbon to Madeira; a flight performed to test the accuracy of the Precision Sextant and the "path corrector" [3].

atlantic flight from Lisbon, Portugal to Rio de Janeiro, Brazil, through Cape Verde. Above all, Coutinho and Cabral sought to prove that air navigation could be just as accurately pursued as sea navigation, by deploying sextants and other available astronomical devices. Lisbon-Rio de Janeiro had to include several steps: Lisbon, Las Palmas, Gando, S. Vicente, S. Tiago, Penedos (St. Peter \& St. Paul's Rocks), Fernando de Noronha, Recife, Baía, Porto Seguro, Vitória and Rio de Janeiro. On 30 March 1922 at Lisbon, Gago Coutinho and Sacadura Cabral onboard the "Lusitânia" (Figure 7), started a journey that later became known as the First Flight from Europe to the South Atlantic. On 18 April 1922, during this Journey, the "Lusitânia", while at sea landing at Penedos stopover, floaters were destroyed by the crest of a stronger wave and the airplane tilted and sank soon thereafter. On 11 May, navigators resume their flight schedule with a second seaplane "Portugal'; sadly, after 6 hours of flight, the engine stopped due to fuel carburetion hiccups, leading to a forced sea landing and sinking hours later. Navigators were rescued by a freighter on its way from Cardiff to Rio de Janeiro. A third Fairey 17 named "Santa Cruz" was then shipped to Fernando Noronha in a Portuguese Navy ship "Carvalho de Araújo" and the journey was immediately continued without incidents. Finally the trip was concluded only with internal means of navigation after 62 hours of flight [6]. Figure 8 illustrates the route of the First Flight from Europe to the South Atlantic. After 1922, Coutinho made a second crossing of the South Atlantic. In 1931 the Dornier manufacturer invited him to travel as guest of honor, however he insisted to travel as the co-navigator; the hydroplane was the giant 


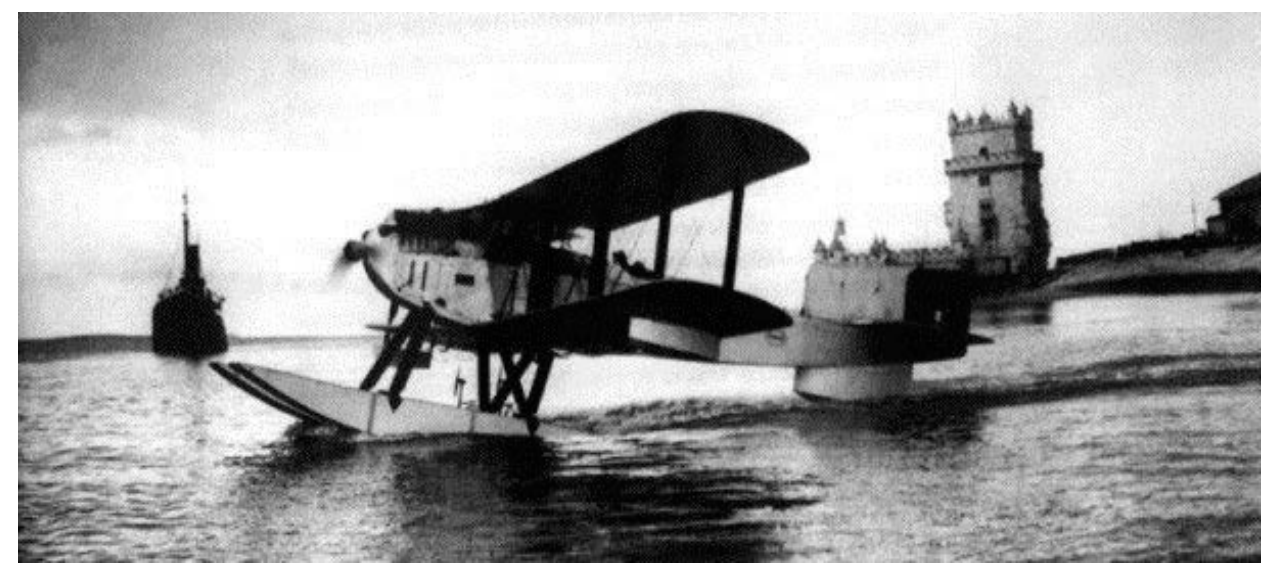

Figure 7. The seaplane "Lusitânia" piloted by Sacadura Cabral (along with Gago Coutinho as a navigator) preparing its take-off from Lisbon, at 30 March 1922 [6].

DO. X, with 12 engines of $610 \mathrm{hp}$ each one, weighing more than 50 tons. Aerial navigation onboard Dornier seaplanes were performed essentially with Coutinho's precision sextant.

\subsection{Gago Coutinho and Other Important Aerial, Naval and Railway Journeys}

Other more important journeys on its own appointments were: an Around the World cruiser Tour in 1898-1899 with stopovers at Aden, Ceylon (Sri Lanka), Singapore, Timor, Macau, Hong Kong, Shanghai, Yokohama, Hawaii, S. Francisco, Chicago, Niagara, New York, Liverpool, Lisbon; on 1927: Lisbon, Funchal, Rio de Janeiro, New York, Paris and return to Lisbon; on 1933: from Angola to Mozambique by Train; on 1935: excursion to North Cape in the Milwaukee cruiser; on 1939: a Journey with stopovers at Lisbon, Rio de Janeiro, Pará, Panama Canal, Hollywood, Santa Fé, San Francisco, Great Canyon, Kansas City, Chicago, Niagara, New York and Paris. He travels from Lisbon to Rio de Janeiro in 1923, 1925, 1927, 1929, 1931, 1932, 1934, 1936, 1938, 1939, 1941, 1943, 1945 and 1946. In 30 March 1955, with 86 years, he performs its last flight from Lisbon to Rio de Janeiro by traveling on a DC-4 of TAP-Transportes Aéreos Portugueses with the purpose to study the organization of regular flights from Portugal to Brazil (Figure 9).

\subsection{Gago Coutinho’s Precision Sextant: “System Admiral Gago Coutinho"}

Gago Coutinho never patented his precision sextant, which dates back to 1919; he used it successfully in 1921 and 1922. The precision sextant adoptions has proved to be quite successfully, proved itself again a great precision along the First Aerial South Atlantic Night Crossing [3] [6] [11] [13], from Lisbon to Rio de Janeiro in 1927 with Captain Jorge Castilho as navigator.

This journey was performed with the use of a Dornier Wal seaplane named "Argos", which has been purchased with the aim to perform a Portuguese Circumnavigation Flight, an idea conceived by Coutinho and Cabral, several years back; unfortunately 


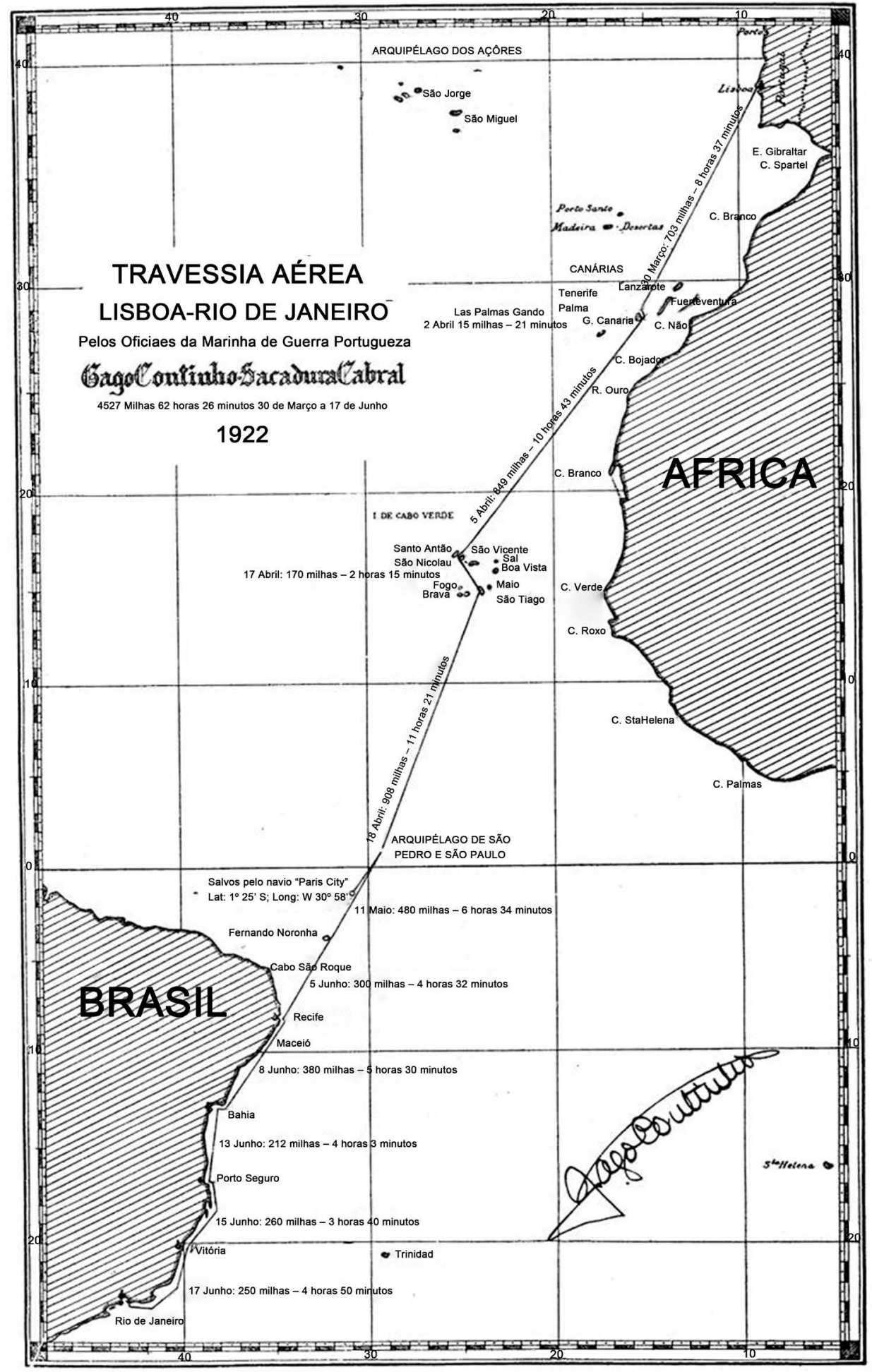

Figure 8. Portuguese propaganda showing the route of the First aerial crossing of the South Atlantic, managed by Gago Coutinho and Sacadura Cabral [3] [6].

Cabral lost his life in a plane crash in the North Sea on 15 November 1924 before carrying out this dream; after, Coutinho lost the Circumnavigation Flight interest because 


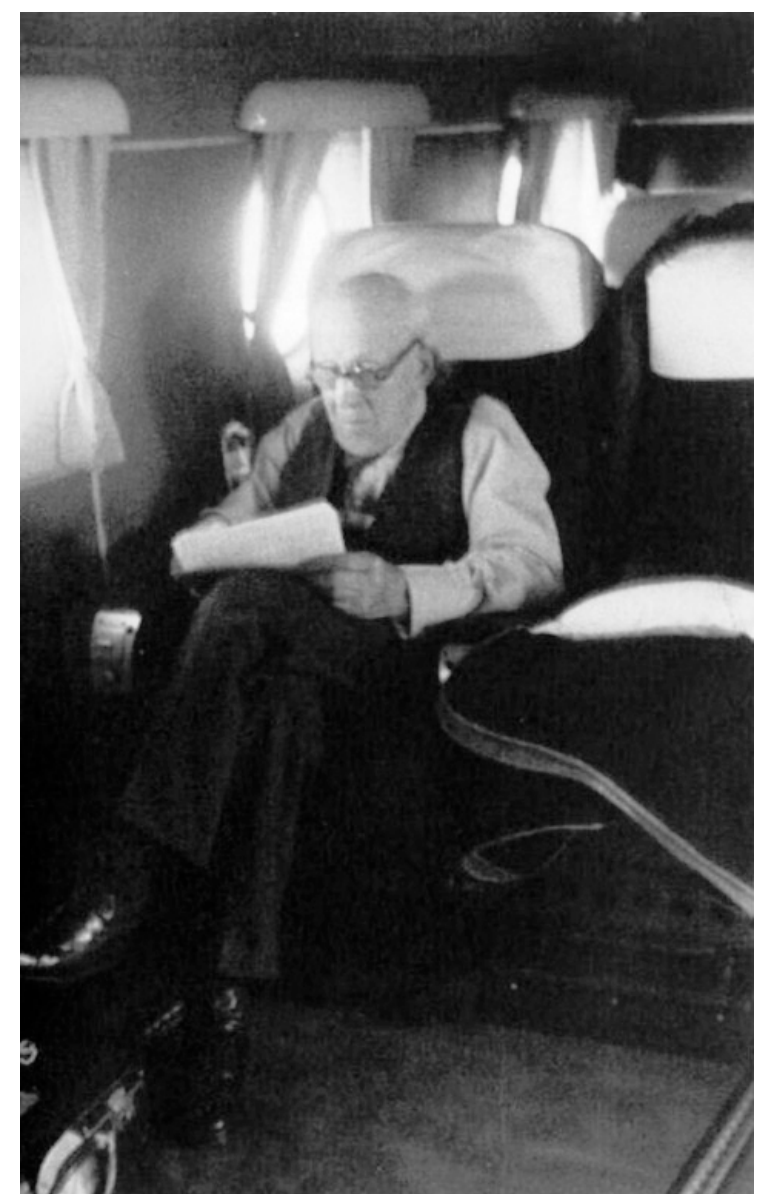

Figure 9. Gago Coutinho onboard a DC-4 belonging to Transportes Aéreos Portugueses, traveling with the purpose to study the organization of regular flights from Portugal to Brazil [12].

it was no longer meaningful without his friend. References to scientific aerial navigation methods and devices created in Portugal were published in almost all aeronautical magazines: Nautical Magazine (1923); United States Naval Proceedings, Navigatione Aerea, from Italy; Icaro and Boletin Oficial de Aero Club de España; Conquete de l'air, from Belgium; L'air, French revue; Navigacion Aerea, from J. Aymat, Barcelona, 1928 and Avigation, from Bradley Jones, London, 1931. In 1929 Captain Witten man navigated the Graf Zeppelin around the world using a Coutinho sextant. With this spectacular record, the design was the hit of the 1930 Berlin Air Show. Until 1930, several countries had acquired this instrument: Portugal, Germany, Japan, France, Spain, U.S.A., Chile, Italy, Netherlands, Sweden, Argentina and Bolivia. The Deutsche Lufthansa created an air navigation course in the Naval School of Lubeck, where was thought the Coutinho's sextant and its path corrector. Fr. Nissen managed to expand the path corrector on air navigation above land, the Coutinho-Fr. Nissen path corrector. During the IV Congress of the International Air Navigation, Rome, 1927, Coutinho and Castilho, presented and defended the Portuguese aerial navigation methods and 
devices. In 1932 also in Rome, during the I International Congress of Transoceanic Aviators, highest honors were given to the Portuguese crossings of the South Atlantic as well as to their methods and devices of navigation; they were both used by many of the major airlines in the World throughout the 1930's [3] [6]. The Portuguese Navy, who had rights to the development, contracted with the prestigious German firm of C. Plath for its production; in fact, Coutinho regularly provided to C. Plath all the sextant improvements implemented (by himself or by Jorge Castilho) until 1938. After II World War, sextants evolved to become practical. The air transport aircraft came to be equipped with domes of transparent plastic, requiring no corrections to the readings, such as predicted by Coutinho. In February of 1969, by the Coutinho's centenary birth, Frank Borman has been at Portugal (Figure 10). The Commander of the Apollo-8, the first that orbited the Moon from 21 to 27 December 1968, gave a lecture at the Portuguese National Laboratory of Civil Engineering. He explained that the principle of Gago Coutinho was present in the Apollo-8 flight. In fact, "a sextant used in aeronautics for the first time in the world by the Portuguese genius" was mounted to a telescope. He detailed that these instruments was connected to a computer, which indicated that the final accuracy of the error was 0.001 degree. In 1971, Francis Millet Rogers, from Harvard University write a book entitled "Precision Astrolabe, Portuguese Navigator and Transoceanic Aviation" published in Lisbon by the Academia Internacional da Cultura Portuguesa, and distributed in the U.S.A. by W. S. Sullwold, Tauton, Mass. In

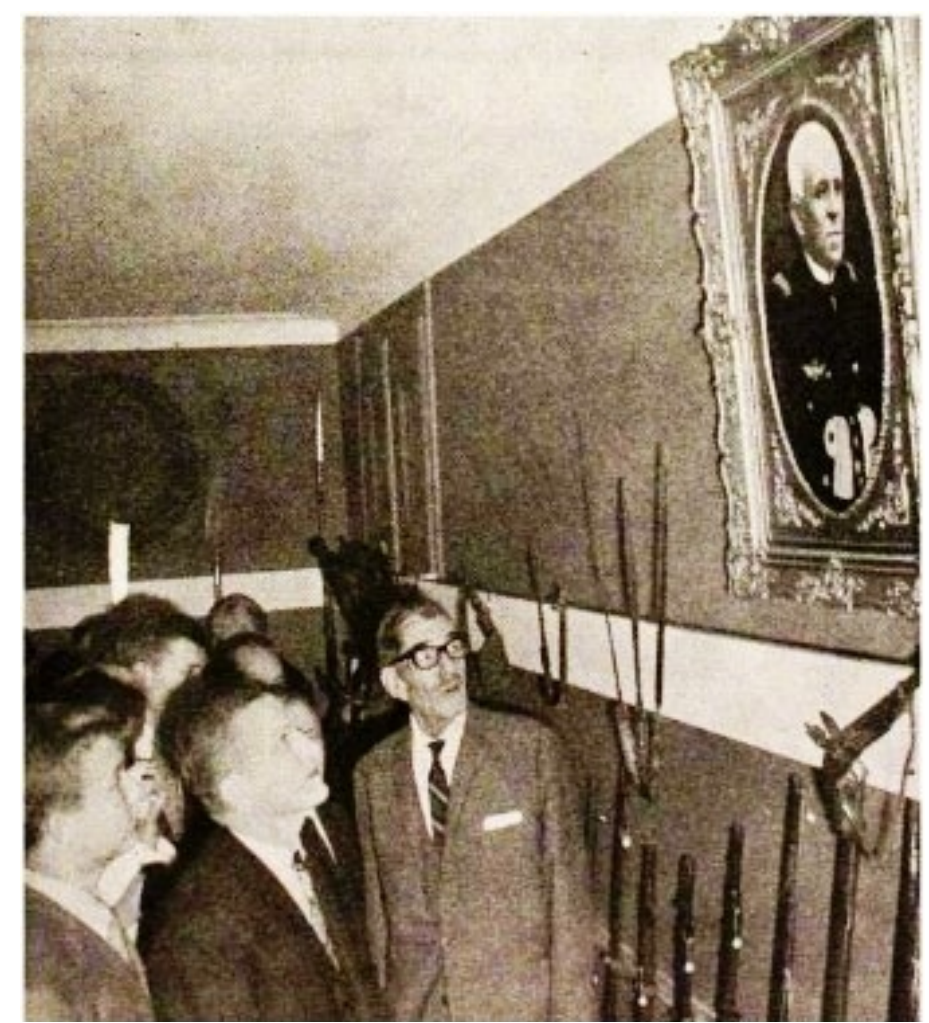

Figure 10. The Apollo 8 Commander Frank Borman on its visit to Portugal, honoring Gago Coutinho [6]. 
1973, Colter, H. C. publishes his work entitled "An Early Portuguese Contribution to Air Navigation", in the Journal of Navigation, (Volume 26, Issue 03, July 1973, pp. 382-385). In this paper, the author made references to Coutinho's process of navigation "which made the calculations on the eve of the flight so that the line position was drawn in the flight chart nearly 5 minutes after the end of observation, and while crossing the Atlantic South, close to equator line, this time was reduced to 3 minutes" was an unprecedented simplification studied by Coutinho.

\subsection{Gago Coutinho's Scientific, Historical and Literary Works}

From 1925 to 1958 Gago Coutinho dedicated himself to the history of navigation and discovery. His scientific, historical and literary work includes 1 book, 17 communications to the Portuguese Sciences Academy, 2 Communications to the Portuguese Academy of History, 2 communications to the Geographic Society of Lisbon, 6 International Congress Thesis, 3 National Congress Thesis, 23 Conferences, 25 Speeches, 2 Lectures, 5 Reports, 27 Collaborations with the Geographic Society of Lisbon, 16 Collaborations with Naval Military Club. However, he published numerous works in periodic publications, many of these works having been put together into two volumes organized and prefaced by Commander Moura Brás: "A náutica dos descobrimentos”; "Os descobrimentos marítimos vistos por um navegador: colectânea de artigos, conferências e trabalhos inéditos do Almirante Gago Coutinho", Lisbon, Agência Geral do Ultramar, 1951-1952, in two volumes. Many other texts were published in two volumes edited by Teixeira da Mota: "Obras completas de Gago Coutinho”, Lisbon, Junta de Investigações do Ultramar, 1972.

\subsection{Gago Coutinho's Insignias, Honors and Tributes}

Admiral Gago Coutinho received the highest levels of national and international tributes. His Portuguese Military tribute included several insignias: The "Grã-cruz da Ordem Militar da Torre, Espada, Valor, Lealdade e Mérito"; the "Grã-cruz da Ordem Militar de Avis"; the "Grã-cruz da Ordem Militar de Cristo"; the "Grã-cruz da Ordem Militar de Santiago da Espada"; the "Grã-cruz da Ordem do Império Colonial”; the "Medalha de Ouro dos Serviços Distintos and Medalha Comemorativa do Exército Português com passadeira Timor, 1912-1913" (Figure 11). His Foreign Military tribute included several insignias: the "Grã-Cruz da Ordem de Mérito Aeronáutico", and the "Grã-Cruz da Ordem Nacional do Cruzeiro do Sul", both from Brazil; the "Gran Croce dell'Ordine della Corona d' Italia"; the "Grand Croix de I'Ordre du roi Léopold", from Belgium; the "Gran Cruz de la Orden Militar y Naval, from Spain and the "Commandeur de la Légion d Honneur", from France (Figure 12).

In 1923 Coutinho was commissioned to undertake the study of the experimental results of modern methods of aerial survey in Italy, France and Brazil. In 1926 was appointed Honorary Director of the Portuguese Naval Aviation, earning the right to use the pilot aviator distinctive topped with two palms. In 1928 he was appointed by the War Ministry to be the chairman of the Committee of Reorganization of Geographical, 

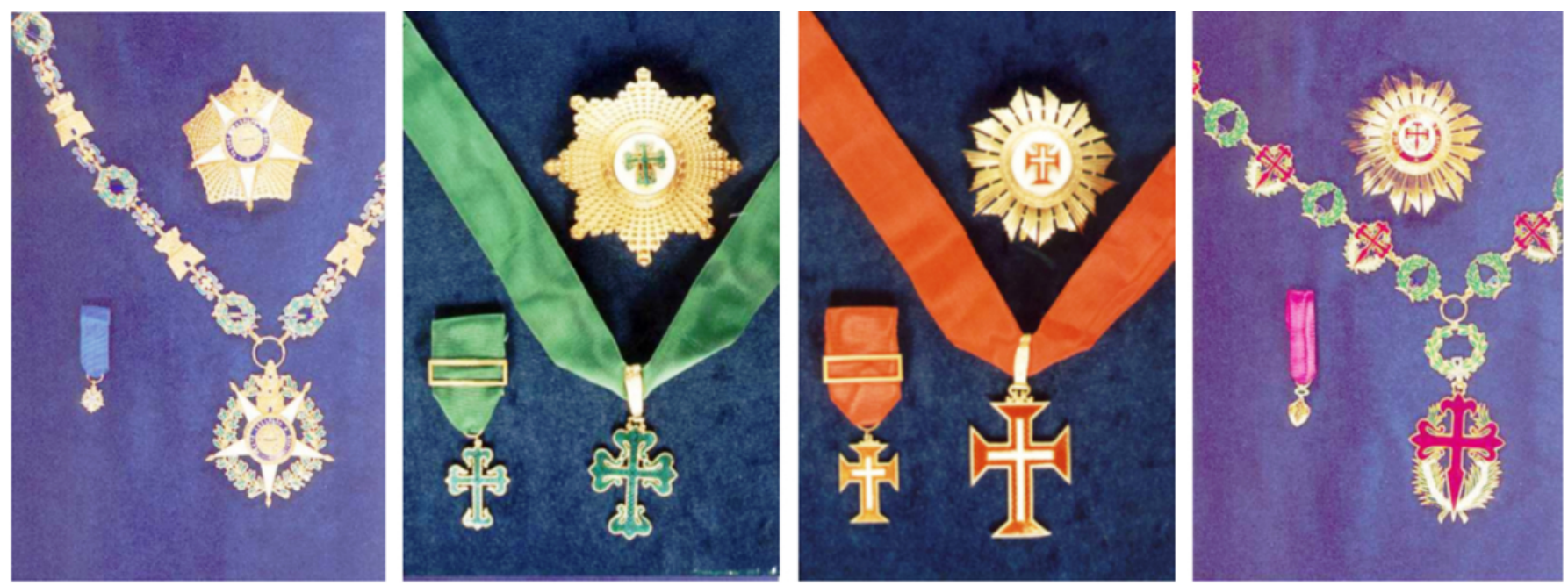

Figure 11. Some Portuguese Military Honoristic Insignias given to Gago Coutinho: from left to right, the "Grand Cross of the Ordem Militar da Torre, Espada, Valor, Lealdade e Mérito"; the "Grand Cross of Ordem Militar de Avis"; "Grand Cross of the Ordem Militar de Cristo" and the "Grand Cross of the Ordem Militar de Santiago da Espada".
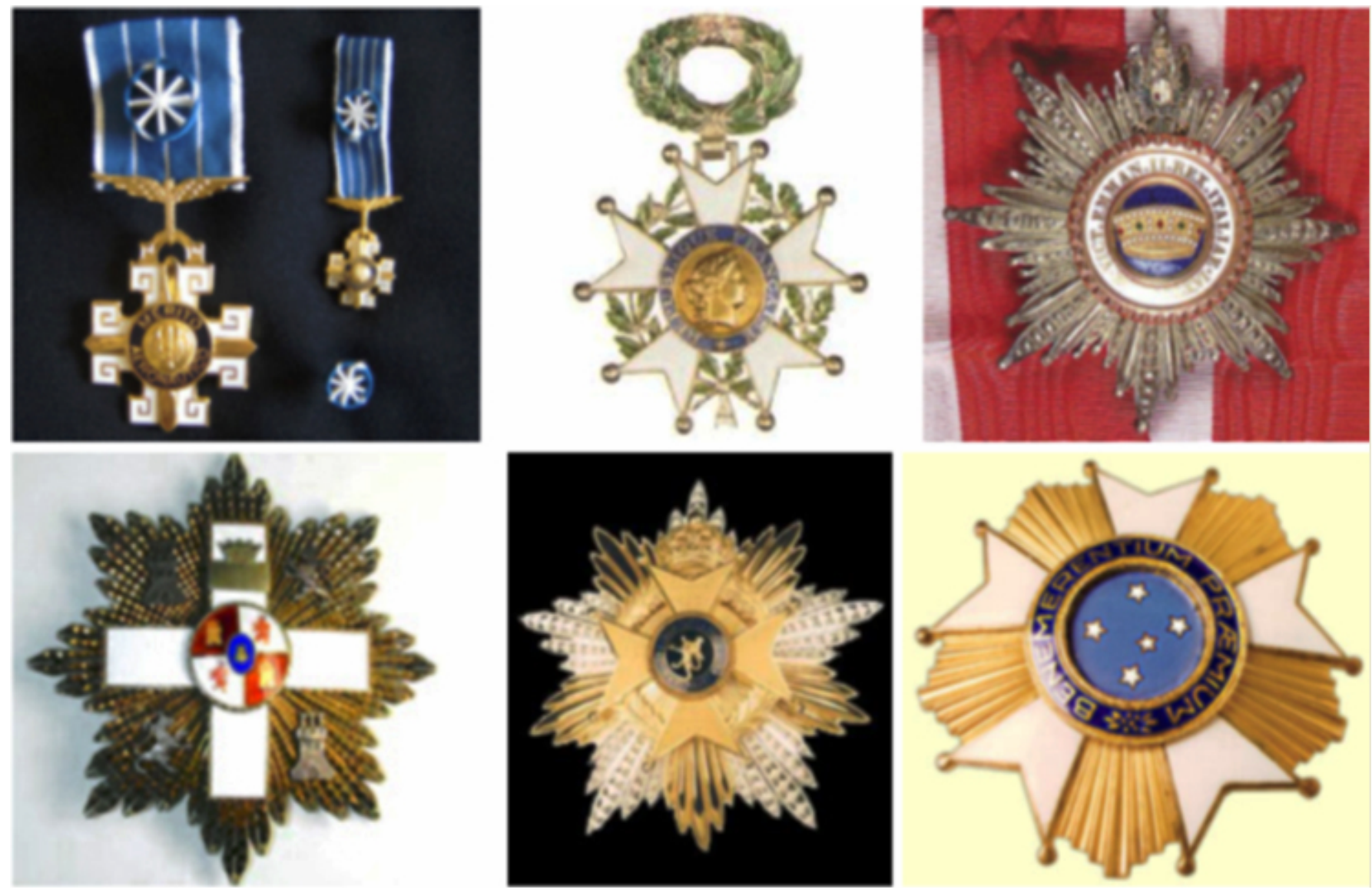

Figure 12. Some Foreign Military Honoristic insignias given to Gago Coutinho: On top, from left to right: "Grand Cross of the Ordem de Mérito Aeronáutico" (Brazil); "Commander Cross of the Legion d’Honneur" (France); "Grand Cross of the Ordine Della Corona de Italia" (Italy); on bottom, from left to right: “Grand Cross of the Orden Militar” (Spain); "Grand Cross of the l'Ordre du Roi Leopold” (Belgium) and "grand cross of the Ordem Nacional do Cruzeiros do Sul" (Brazil). 
Cadastral and Cartographic Data. In the same year was commissioned to carry out mapping studies in France and Italy, and shortly thereafter sent to Brazil to take stock of cartographic documents relevant to the History of Portugal. In 1930 he collaborated in the Committee for the Navy Museum and the following year was appointed to the Committee responsible for organizing the Nuno Alvares Pereira centenary celebrations. He also published works on the theory of restricted relativity. He was a member of the "Academia de Ciências de Lisboa" (Lisbon Academy of Sciences, since 1928), member of the "Academia de Ciências de Portugal" (Portuguese Academy of Sciences), a member of the "Academia de História" (History Academy), a member of the "Institute of History and Geography" of Rio de Janeiro, honorary member and Gold Medal of the "Sociedade Geográfica de Lisboa" (Geographical Society of Lisbon, and member of the "Sociedade Geográfica" (Geographical Society) of Brazilian cities of Rio de Janeiro, Pernambuco, Baía and Espírito Santo. He was Honorary Fellow of the Club de Engenharia of Rio de Janeiro. In 1933 he collaborated in the responsible committee for the study of the project of a monument to Infante D. Henrique at Sagres, Portugal. In the same year he returned to Mozambique for geographic work. In 1934 as Vice-Admiral he enters in reserve. He was Doctor Honoris Causa by the Universidade de Lisboa and Faculdade de Engenharia do Porto. In 1936 he was appointed to the Advisor Committee of the Historical Exhibition Occupation of the first Congress of the Portuguese Expansion in the world. Retired in 1944, was promoted to Admiral with distinction in 1958. During World War I (1914-1918), he drew secret routes allowing that ships could escape to the enemy submarines and aided the Allied blockade against the Kaiser's Empire. It was an anonymous hero who saved thousands of lives. In 1958 the Combatants League of the Great World War made Coutinho his honorary member [6]. He died in Lisbon a day after completing ninety years, in February $18^{\text {th }} 1959$. The Portuguese Navy, to honor the Admiral Gago Coutinho, christened two ships with his name: the ship A523, a ship of Investigation and Research working for the Hydrographic Institute, and the frigate F473. Portugal pays tribute to Coutinho in philately (Figure 13).

In 1923, Portugal issue orders for a series of 16 stamps on the commemoration of the South Atlantic Crossing. In the centenary of Coutinho's the birth (1969), four commemorative stamps were issued. These stamps circulated more than five years. In the fiftieth year of the first air crossing of the South Atlantic (1972), four stamps are issued to celebrate the occasion. These stamps circulated for more than ten years. Also in 1972, Angola, Macau, Mozambique, Sao Tome and Prince and East Timor-issued a stamp, celebrating that date. In 2009, by the $50^{\text {th }}$ anniversary of his death, Portugal issued a Postcard elusive to date. Spain, in 1930 in one of nine commemorative stamps of the Universal Exposition of Seville, honored the Portuguese navigators on the Crossing the South Atlantic. Portugal also pays tribute to Coutinho in bank notes (Figure 14). In Portugal, was issued a bank note allusive to the Admiral and the Crossing of the South Atlantic, circulating from 1978 to 1986. In Mozambique in 1972, three issued bank notes were issued. These bank notes circulated till the Country's independence. Other kinds of honors were given to Coutinho: villages christened with his name. Several cities of Portugal and former colonies, paid tribute to the Admiral, by christening streets, 

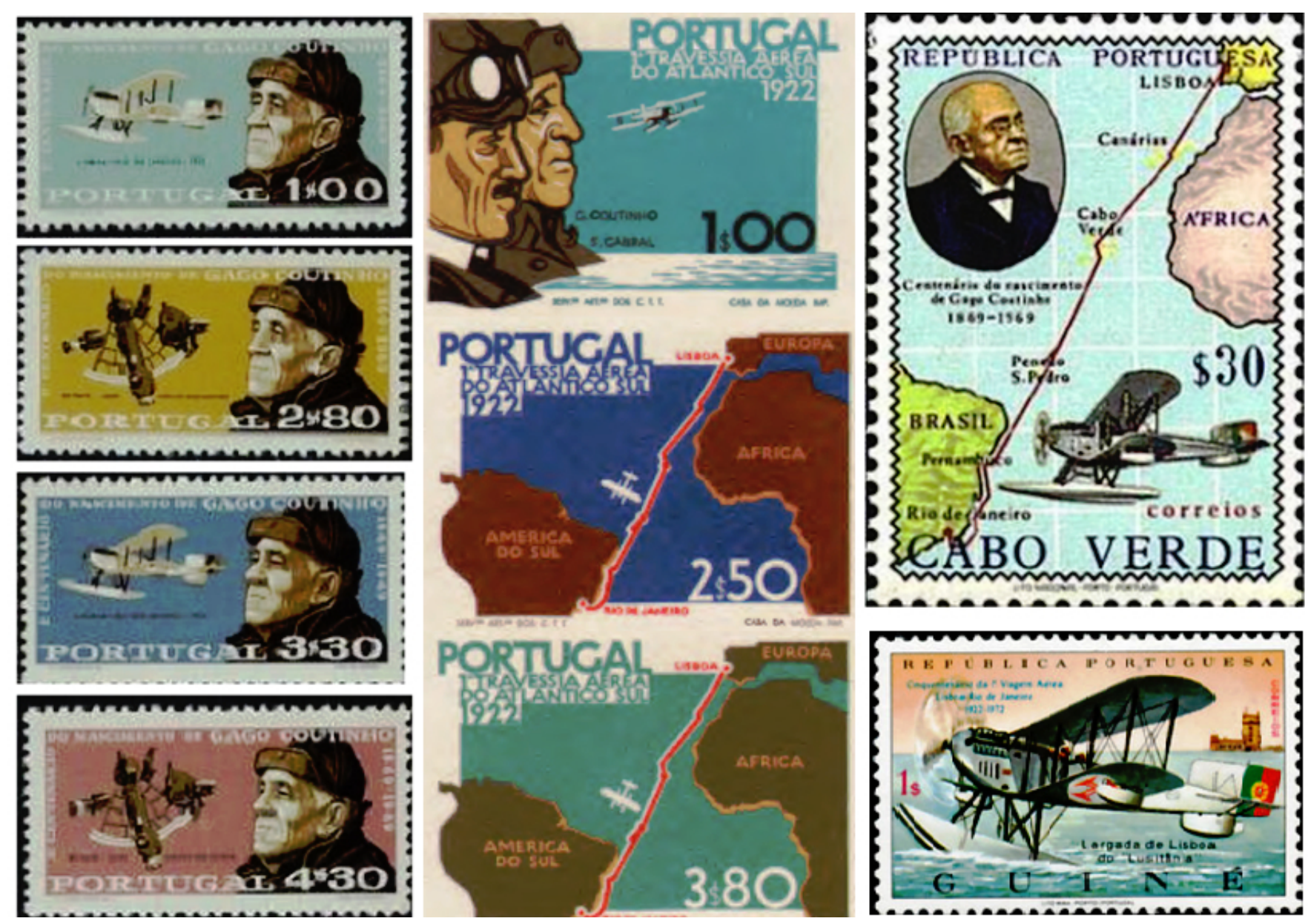

Figure 13. Some Portuguese philately tribute to Gago Coutinho: on the left, from top to bottom, the four stamps celebrating the centenary of his birth (1969); in the middle; three of the four stamps celebrating the fifty years of the South Atlantic Crossing (1972); on the right on top, a stamp from Cape Verde celebrating the South Atlantic Crossing, and at the bottom, one stamp form Guinea, celebrating the first South Atlantic Aerial Crossing.

avenues, squares, airports, with his name. He was several times an honorary citizen, also honorary member of charitable and recreation communities.

\section{Conclusion}

Gago Coutinho was born in Lisbon on 17 February 1869. He served the Portuguese Navy almost exclusively as "officer in charge of navigation". He developed a new model of sextant that could be used to measure the altitude of a star when flying without the need of the sea horizon (the precision sextant). Due to his knowledge of Navigation, Astronomy, Geography and Mathematics, Gago Coutinho received several important official medals and prizes, including the $\mathrm{PhD}$ Honoris Causa from the Universities of Lisbon and Oporto, and authored several scientific publications. He had important missions in Africa and Asia where he employed his scientific knowledge. By 1919, he develops a new model of sextant that could be used to measure the altitude of a star without the need of the sea horizon, and used it successfully in the First Flight from 

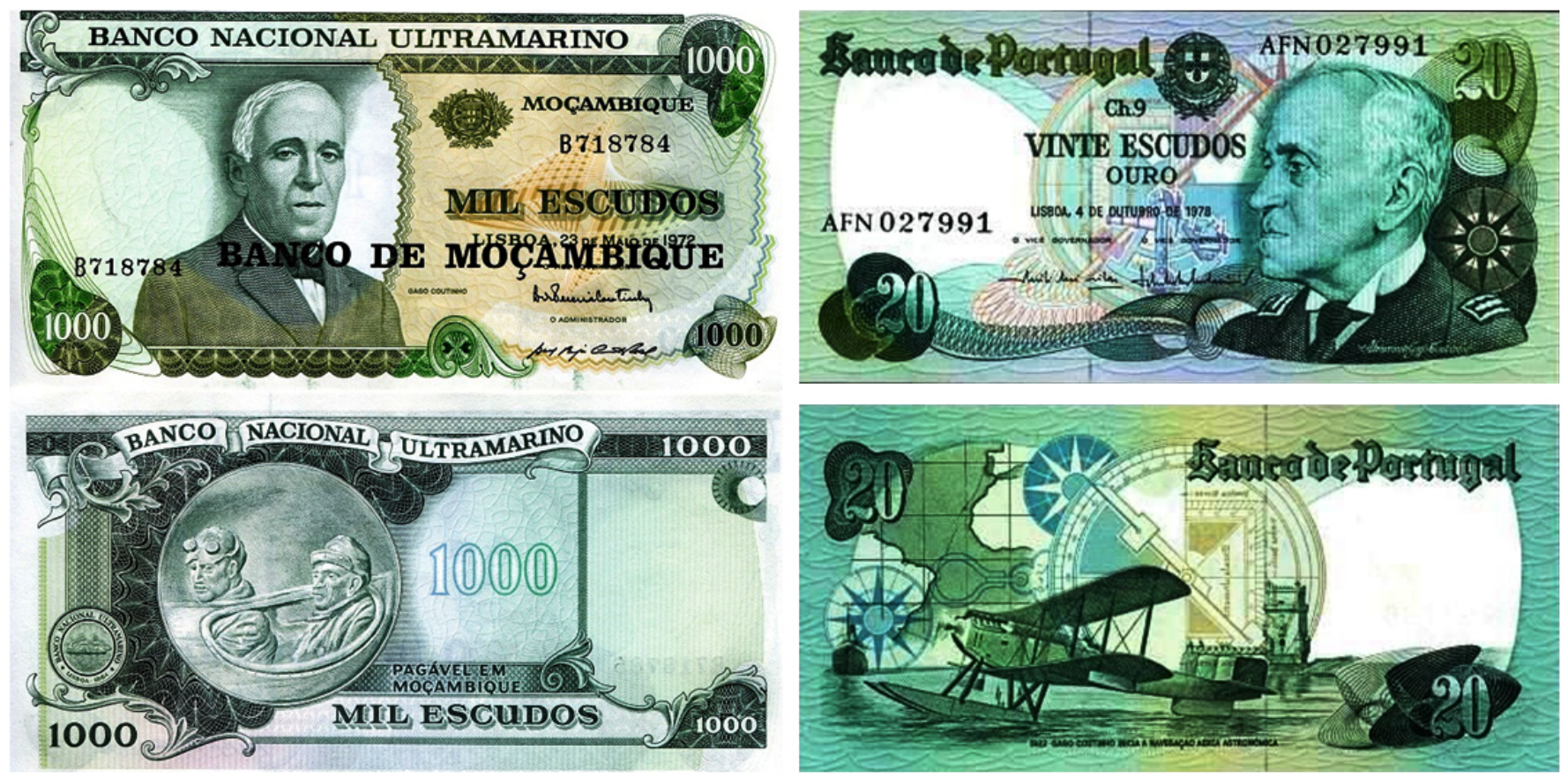

Figure 14. Some paper money tribute to Gago Coutinho: on the left, one of the three bank notes issued in Mozambique, circulating from 1972 to 1975; on the right, a bank note issued in Portugal, circulating from 1978 to 1986.

Europe to the South Atlantic in 1922. He continues his work by improving its sextant (called by Coutinho as "Precision Astrolabe") until 1938. Their precision sextant was successfully used in Astronautics fifty years after its first use in Aeronautics.

\section{Acknowledgements}

The present work was performed in the scope of the activities of the AeroG-Aeronautics and Astronautics Research Center (http://aeronautics.ubi.pt). The financial support of the Portuguese Ministry of Science through the Science and Technology Foundation (FCT) is gratefully acknowledged.

\section{References}

[1] Albuquerque, L. (1989) Curso de História da Náutica. Publicações Alfa, Lisboa.

[2] Boléo, J.O. (1972) Gago Coutinho e Sacadura Cabral. Edição da Comissão Nacional das Comemorações Sociedade de Geografia de Lisboa.

[3] Corrêa, P. (1969) Gago Coutinho, Precursor da Navegação Aérea. Portucalense Editora, Porto.

[4] Lemos, S. and Oliveira, C.M. (2000) O Almirante Gago Coutinho. Instituto Hidrográfico, Lisboa.

[5] Reis, M. and Cortesão, A. (1969) Gago Coutinho Geógrafo, Coimbra, Junta de Investigações do Ultramar, 1970, sep. de Memórias da Academia das Ciências de Lisboa, Tomo XIII.

[6] Cardoso, E.P.C. (1981) História da Força Aérea Portuguesa, Vol. II, Edição Cromocolor, Lda, Lisboa, Printed in Gratelo,S.A.R.L., Amadora.

[7] Corrêa, P. (1964) Sacadura Cabral, Homem e Aviador. Edição do Autor, Bertrand, Lisboa. 
[8] Silva, A.R.R., Morgado, C.M.P., Barata, J.M.M. and Neves, F.M.S.P. (2009) First Flight from Europe to the South Atlantic-Gago Coutinho and Sacadura Cabral. Proceedings of the 47 th AIAA Aerospace Sciences Meeting and the New Horizons Forum and Aerospace EXhibit, 21, 13670-13676. http://arc.aiaa.org/doi/abs/10.2514/6.2009-1162 http://dx.doi.org/10.2514/6.2009-1162

[9] Barata, J.M.M., Mendes, A.L.M., Morgado, C.M.P., Neves, F.M.S.P. and Silva, A.R.R. (2009) The Origins of Scientific Aircraft Navigation. Proceedings of the 45th AIAA/ASME/ $S A E / A S E E$ Joint Propulsion Conference \& Exhibit and 7 th International Energy Conversion Engineering Conference, 3, 1974-1980.

http://arc.aiaa.org/doi/abs/10.2514/6.2009-5022 http://dx.doi.org/10.2514/6.2009-5022

[10] Neves, F.M.S.P., Barata, J.M.M. and Silva, A.R.R. (2016) Sacadura Cabral and the Dawn of Portuguese Aviation. Open Journal of Applied Sciences, 6, 16-30. http://dx.doi.org/10.4236/ojapps.2016.61003

[11] Neves, F., Barata, J. and Silva, A. (2016) First Aerial South Atlantic Night Crossing. Advances in Historical Studies, 5, 19-35. http://dx.doi.org/10.4236/ahs.2016.51003

[12] Pinto, R.M.C. (2014) Gago Coutinho, O último grande aventureiro Português. Eranos Edições e Multimédia, Lda, Lisboa.

[13] Beires, J.S. (1927) Asas que naufragam: De como o avião Argos, ao fim de dezasseis mil quilómetros de vôo, se perdeu aolargo das costas da Clevelândia e do mais que durante a viagem se passou. $1^{\text {a }}$ Edição, Lisboa: Livraria Clássica Editorade A. M. Teixeira \& $C^{a}$. (Filhos).

[14] Cabral, S. (1921) Coutinho-Sacadura Course Corrector. Premier Congrés International de la Navigation Aérienne, Paris, 15-25 November 1921, 112-114. http://naca.central.cranfield.ac.uk/reports/1922/naca-tm-132.pdf

[15] Nowell, C.E. (1982) The Rose-Colored Map: Portugal's Attempt to Build an African Empire from the Atlantic to the Indian Ocean. Junta de Investigações Científicas do Ultramar, Estudos de Cartografia Antiga, Lisbon.

\section{Submit or recommend next manuscript to SCIRP and we will provide best service} for you:

Accepting pre-submission inquiries through Email, Facebook, LinkedIn, Twitter, etc. A wide selection of journals (inclusive of 9 subjects, more than 200 journals)

Providing 24-hour high-quality service

User-friendly online submission system

Fair and swift peer-review system

Efficient typesetting and proofreading procedure

Display of the result of downloads and visits, as well as the number of cited articles Maximum dissemination of your research work

Submit your manuscript at: http://papersubmission.scirp.org/

Or contact ojapps@scirp.org 